\title{
Study of relationship between CRP, bilirubin and selected anthropometric parameters with hypertension
}

\author{
Rao K. S. $P^{1}$, Prasad J. $R^{2}$, Atif $M^{3}$, Bhat R, Rao G ${ }^{4}$, Shivaraja Shankara Y. $M^{5}$ \\ ${ }^{1}$ Dr K. S. Prakash Rao, Assistant Professor ${ }^{2}$ Dr Jyothi R Prasad, Associate Professor, ${ }^{3}$ Dr Mohamed Atif, Resident, \\ ${ }^{4}$ Dr Ramachandra Bhat, Professor, ${ }^{5}$ Dr. Gopala Rao, Professor. All affiliated with Department of Medicine, K.V.G. \\ Medical College, Kurunjibag, Sullia-Karnataka, India, ${ }^{6}$ Dr Shivaraja Shankara Y. M, Professor, Department of \\ Bio-Chemistry, K. V. G. Medical College, Kurunjibagh, Sullia-Karnataka, India.
}

Address for Correspondence: Dr K. S. Prakash Rao, Assistant Professor, Department of Medicine, K. V. G. Medical College, Kurunjibag, Sullia -Karnataka, INDIA. E-mail: ksprkrao0@gmail.com

\begin{abstract}
Background: There are many recent studies showing that hypertension, and cardio-vascular disease is linked to inflammation. The higher CRP levels are significantly correlated with hypertension. CRP estimation is used as a surrogate marker in evaluation and predicting the prognosis of all hypertensive patients. Many of the epidemiologic studies had shown the association of CRP levels with future cardiovascular events and hypertension. Bilirubin has been shown to be an effective antioxidant both in vitro and in vivo. The excess body fat and distribution is an important contributor to the association between obesity and high BP. Aims and objectives: The objective was to study the relationship between CRP, Bilirubin and selected anthropometric parameters among both hypertensive and non hypertensive subjects. Methods: We have conducted a hospital based descriptive observational study using purposive non random sampling method on 150 subjects; 87 hypertensive and 77 were non hypertensive. Age, systolic BP, diastolic BP, weight, height, waist circumference, hip circumference, SAD, total Bilirubin, T cholesterol, HDL-C, Triglycerides, LDL-C were primary continuous variables. BMI, WHR, WHtR were taken as secondary variables. Results: CRP, Waist circumference, WHtR and SAD have a positive correlation with both systolic and diastolic BP. Odds ratio was 12.18 for CRP. Total Bilirubin levels have a negative correlation with systolic and diastolic BP. Odds ratio was 7.81. Diastolic BP had positive correlation with Weight, Hip circumference and BMI. Conclusion: We had demonstrated elevated CRP, low Bilirubin levels, abnormal SAD and Waist circumference were associated with blood pressure levels. These parameters are useful and cost-effective tool for predicting and evaluating Hypertension.
\end{abstract}

Key words: SAD, Bilirubin, Anthropometry, Hypertension

\section{Introduction}

Hypertension is a global challenge. Risk factors for hypertension have only been partially understood. Some studies have shown that hypertension is associated with a low grade inflammatory pathology and this process is also involved in endothelial dysfunction and atherosclerosis $[1,2]$. The loss of vasodilator and antiatherogenic properties is probably because of an inflammatory marker CRP which is thought to decrease nitric oxide production in the endothelial cells and thus promoting vasoconstriction, platelet adhesion and thrombosis [3]. Thus many studies suggest a strong

Manuscript received $27^{\text {th }}$ April 2016

Reviewed: $8^{\text {th }}$ May 2016

Author Corrected: $18^{\text {th }}$ May 2016

Accepted for Publication 31 $1^{\text {st }}$ May 2016 relationship between CRP and cardiovascular disease [4]. Further CRP is an early marker of systemic inflammation and it can also be easily detected by blood examination. Hence CRP estimation should be recommended in evaluation and in predicting the prognosis of all hypertensive patients.

Several studies have also reported bilirubin to be an effective antioxidant which scavenges peroxyl radicals and also as a substance which suppresses oxidation of LDL cholesterol, thus suggesting its protective role in hypertension and cardiovascular disease and so protecting one from mortality risk secondary to coronary heart disease [5]. 
In certain studies, hemeoxygenase -1 has been shown to decrease the BP levels and sometimes the development of hypertension itself. The reason could be that hemoxygenase 1 causes increased bilirubin levels in the body which thus exerts its antihypertensive property $[6,7]$.

Obesity is a well known risk factor for most of the non communicable diseases and especially cardiovascular disease and hypertension [8]. Anthropometry is one of the most commonly used non invasive technique to measure obesity [9]. Other than the commonly used indicators of obesity like BMI and WHR, sagittal abdominal diameter which measure visceral fat $[10,11]$ and another indicator waist circumference is finding an important role as a marker of obesity [9]. The studies on western and urban Indian population had shown correlation between hypertension and different anthropometric parameters $[12,13,14,15]$. The aim of this study was to find any association between hypertension and different anthropometric and certain other biomarkers in rural South Indian population.

\section{Material and Methods}

Study design and study population: The present hospital based study conducted on 150 subjects, among which 87 were hypertensives and 77 were non hypertensives visiting medicine OPD at KVG Medical College Hospital, Sullia, Karnataka. It was a descriptive observational study done from 1 October 2014 to 30 April 2015 using purposive non random sampling method. All subjects were included in the study.

Inclusion Criteria: The study was conducted among individuals with 40 years of age and above who were not on any medications except anti hypertensives who are willing to be part of our study.

Ethics Statement: The protocol was approved by the Institutional Ethical Committee. Informed consent was obtained from all the study participants.

Exclusion Criteria: Subjects with spinal deformity, abdominal tumor, lump, significant ascites, pregnant females, pathological diseases like cancer, insufficient renal and hepatic diseases and chronic inflammatory pathologies and in whom anthropometric measurements were not feasible [16]. Individuals with high liver test values (which are indicative liver injury or disease). Subjects with Alanine transaminase (ALT) $>40 \mathrm{IU} / \mathrm{L}$ were excluded to avoid a confounding effect by Gilberts syndrome and other hepatobiliary disease. CRP levels can also increase in conditions like acute renal failure, bacterial infections, smoking, meningitis and trauma and patients with these issues will also be excluded from the study [3]. CRP levels above $10 \mathrm{mg} / \mathrm{dLindicates}$ chronic inflammation.

Steps in conducting the data collection: Detailed history was taken. A thorough clinical examination of all patients was done in each subject. Blood pressure was measured thrice with five-minute interval on the left arm with a mercury sphygmomanometer. The average of three readings was considered for analysis. Elderly with systolic BP of $>140 \mathrm{mmHg}$ and/or diastolic BP of $>90 \mathrm{mmHg}$ and/or those on medications for hypertension were considered as hypertensives [17].

Complete laboratory work up was also done:-

1. Serum CRP levels

2. Lipid profile: Serum total cholesterol, HDL, LDL and triglycerides

3. Serum Bilirubin, total and direct

4. Fasting and postprandial plasma glucose

5. Renal function tests

6. Standard 12 lead ECG.

7. X-Ray chest PA view

Early morning blood samples were obtained from all patients after clear instruction that thet have to fast for 12 hours over night. The level of C-reactive protein was determined by latex-enhanced nephelometry method having sensitivity $0.5-320 \mathrm{mg} / \mathrm{L}$ and could not detect CRP levels of $<0.5 \mathrm{mg} / \mathrm{L}$ (AGAPEE- MISPA-1 Autoanalyser. Total Bilirubin was determined by modified dimethyl sulfoxide DMSO method which is having the sensitivity $0.01-20 \mathrm{mg} / \mathrm{dL}$. (AGAPPEMISPA Nano Autoanalyser). Lipid profile by AGAPEMISPA Nano Autoanalyser. (TC-cholesterol oxidase method, TG-glycerol 3-phosphate oxidase method, HDL-C by direct qualitative determination, LDL-C by calculation).

Anthropometric measurements like weight and height of the subjects were measured using appropriate standard equipment and procedures. Weight was measured with minimum clothing using a digital weighing scale (nearest to $100 \mathrm{mg}$ ). Measurement of height was done using a stadiometer, with the subject made to stand with feet together after removing the footwear. BMI was calculated as weight $(\mathrm{Kg})$ divided by height in meters square. Subjects were classified as overweight and obese based on the WHO recommended 
cut off values [18]. Waist circumference $>90 \mathrm{~cm}$ and $>80 \mathrm{~cm}$ were considered as obese for men and women respectively, to calculate abdominal or central obesity [19]. Waist circumference (WC) was measured according to WHO criteria in standing position after normal expiration, midway between the lower rib margin and the iliac crest .

The waist-hip ratio is the index of regional distribution of body fat. It is the ratio between the waist circumference values and the hip circumference (HC). The anatomical place used for assessment of $\mathrm{HC}$ was the height of the greater trochanter as recommended by the WHO. Waist hip ratio of 0.80 and more in female and 0.90 and more in males were considered as having abdominal obesity [20].

\section{Results}

The present study was done among 150 subjects of whom 87 were hypertensives and 77 were non hypertensives.

Table-1: Background Characteristics of Study Population.

\begin{tabular}{|c|c|c|c|c|c|c|}
\hline Sl. No & Variable Name & Mean & $\begin{array}{l}\text { Standard } \\
\text { Deviation }\end{array}$ & Median & Minimum & Maximum \\
\hline 1 & Age in years & 58 & 10.4 & 57.5 & 40 & 85 \\
\hline 2 & Systolic BP in mmHg & 133.5 & 23.8 & 130 & 90 & 220 \\
\hline 3 & Diastolic BP in $\mathrm{mmHg}$ & 83.6 & 12.8 & 80 & 60 & 140 \\
\hline 4 & Weight in $\mathrm{kg}$ & 59.1 & 13.7 & 56.5 & 35 & 116 \\
\hline 5 & Height in $\mathrm{cmt}$ & 162.2 & 9.1 & 163 & 133 & 186 \\
\hline 6 & Waist cir. in cmt. & 82.7 & 13.1 & 81 & 54 & 124 \\
\hline 7 & Hip circum in $\mathrm{cmt}$ & 89.5 & 10.7 & 88 & 62 & 137 \\
\hline 8 & SAD in $\mathrm{cmt}$. & 18.65 & 2.29 & 18 & 15 & 25 \\
\hline 9 & $\mathrm{CRP}$ in $\mathrm{mg} / \mathrm{dl}$ & 2.15 & 1.4 & 2 & 0.5 & 6.0 \\
\hline 10 & Tot cholest. in $\mathrm{mg} / \mathrm{dl}$ & 182.9 & 42.3 & 179.5 & 110 & 323 \\
\hline 11 & HDL mg/dl & 43.4 & 10.6 & 41 & 23 & 87 \\
\hline 12 & LDL mg/dl & 121.3 & 41.5 & 112.5 & 30 & 258 \\
\hline 13 & $\mathrm{TG} \mathrm{mg} / \mathrm{dl}$ & 184.5 & 68.1 & 188.5 & 35 & 597 \\
\hline 14 & T. Bilirubin & 0.92 & 0.36 & 0.80 & 0.3 & 2.5 \\
\hline 15 & D. Bilirubin & 0.21 & 0.15 & 0.20 & 0.1 & 1.0 \\
\hline 16 & BMI & 22.5 & 4.8 & 21.7 & 13.7 & 47 \\
\hline 17 & Waist Height ratio & 0.52 & 0.08 & 0.5 & 0.32 & 0.78 \\
\hline 18 & Waist Hip ratio & 0.92 & 0.08 & 0.91 & 0.69 & 1.31 \\
\hline
\end{tabular}

Table 1 shows the background characteristics of the study population. Measures of central tendency for each variable are given in it.
SAD or "supine abdominal height" was measured in supine position to the nearest $0.1 \mathrm{~cm}$ after a normal expiration using a ruler and water level [24]. SAD was measured at the level of iliac crest (L4-5) without clothes in the measurement area.

SAD is the vertical distance between examination table and the umbilical level. SAD cutoffs taken for identifying subjects with an elevated cardio metabolic women [21].

Statistical Analysis:- Statistical analysis was performed using SPSS version 19.0. Z test, ANOVA test, chi square test, odds ratio, correlation and regression were used as a statistical tests for study. risk were taken as $>22 \mathrm{~cm}$ in men and $>20 \mathrm{~cm}$ in 
Table-2- Correlation of various parameters of blood pressure and their odds of having hypertension.

\begin{tabular}{|c|c|c|c|c|c|c|c|c|}
\hline \multirow{2}{*}{$\begin{array}{l}\text { SL. } \\
\text { NO }\end{array}$} & \multirow{2}{*}{$\begin{array}{c}\text { Variable } \\
\text { Name }\end{array}$} & \multicolumn{2}{|c|}{ With Systolic BP } & \multicolumn{2}{|c|}{ With Diastolic BP } & \multirow[t]{2}{*}{$\mathbf{R}^{2}$ Value } & \multirow[t]{2}{*}{ df } & \multirow{2}{*}{$\begin{array}{l}\text { Odds } \\
\text { Ratio }\end{array}$} \\
\hline & & $\begin{array}{c}\text { Corrrelation } \\
\text { Coefficient }\end{array}$ & Significance & $\begin{array}{c}\text { Corrrelation } \\
\text { Coefficient }\end{array}$ & Significance & & & \\
\hline 1 & CRP & 0.341 & $<0.01$ & 0.41 & $<0.01$ & 49.8 & 1 & 12.18 \\
\hline 2 & $\begin{array}{c}\text { Total } \\
\text { Bilirubin }\end{array}$ & -0.29 & $<0.01$ & -0.210 & $<0.01$ & 26.2 & 1 & 7.81 \\
\hline 3 & Weight & 0.12 & $>0.01$ & 0.196 & $<0.01$ & & & \\
\hline 4 & Waist circum & 0.21 & $<0.01$ & 0.214 & $<0.01$ & & & \\
\hline 5 & BMI & 0.12 & $>0.01$ & 0.21 & $<0.01$ & 7.441 & 1 & 2.11 \\
\hline 6 & $\begin{array}{l}\text { Waist Hip } \\
\text { ratio }\end{array}$ & 0.147 & $>0.01$ & 0.09 & $>0.01$ & 3.116 & 1 & 1.77 \\
\hline 7 & HDL & -0.085 & $>0.01$ & -0.107 & $>0.01$ & 2.59 & 1 & 0.598 \\
\hline 8 & LDL & 0.01 & $>0.01$ & -0.007 & $>0.01$ & 0.009 & 1 & 1.03 \\
\hline 9 & $\begin{array}{c}\text { Waist Height } \\
\text { ratio }\end{array}$ & 0.22 & $<0.01$ & 0.219 & $<0.01$ & & & \\
\hline 10 & $\begin{array}{c}\text { Hip } \\
\text { Circumference }\end{array}$ & 0.177 & $>0.01$ & 0.213 & $<0.01$ & & & \\
\hline 11 & SAD & 0.264 & $<0.01$ & 0.309 & $<0.01$ & & & \\
\hline
\end{tabular}

Table 2 shows the correlation of various parameters with blood pressure and their odds of having hypertension. It was seen that systolic BP was correlated with CRP, total Bilirubin, WC, WHt R and SAD whereas Diastolic BP was correlated with CRP, total Bilirubin, weight, BMI, WC, WHt R, HC and SAD.

Table-3: Comparing means of systolic and Diastolic BP with different variable categories used in the study.

\begin{tabular}{|c|c|c|c|c|c|c|c|}
\hline & \multicolumn{3}{|c|}{ Systolic BP } & \multicolumn{3}{|c|}{ Diastolic BP } \\
\hline & & Mean & SD & P Value & Mean & SD & P Value \\
\hline \multirow[t]{2}{*}{ Waist circumf } & LOW $(>85 \mathrm{~cm})$ & 130.5 & 24.7 & \multirow[t]{2}{*}{$>0.01$} & 81.84 & 12.75 & \multirow[t]{2}{*}{$>0.01$} \\
\hline & $\mathrm{HIGH}(>85 \mathrm{~cm})$ & 138.1 & 21.5 & & 86.31 & 12.36 & \\
\hline \multirow{2}{*}{$\begin{array}{c}\text { Total } \\
\text { cholestrol }\end{array}$} & $\operatorname{NORM}(<250)$ & 133.36 & 23.8 & \multirow[t]{2}{*}{$>0.01$} & 83.69 & 12.7 & \multirow[t]{2}{*}{$>0.01$} \\
\hline & HIGH(>250) & 135 & 24.2 & & 82.63 & 13.69 & \\
\hline \multirow{2}{*}{$\begin{array}{l}\text { Waist hip } \\
\text { ratio }\end{array}$} & $\operatorname{NORM}(<0.88)$ & 131 & 25.3 & \multirow[t]{2}{*}{$>0.01$} & 82 & 13.3 & \multirow[t]{2}{*}{$>0.01$} \\
\hline & HIGH(>0.88) & 134.4 & 23.16 & & 84.2 & 12.5 & \\
\hline \multirow[t]{2}{*}{ HDL } & NORM(>40) & 134.3 & 26.5 & \multirow[t]{2}{*}{$>0.01$} & 84.24 & 11.8 & \multirow[t]{2}{*}{$>0.01$} \\
\hline & $\mathrm{LOW}(<40)$ & 132.9 & 21.8 & & 83.13 & 14.22 & \\
\hline \multirow[t]{2}{*}{ LDL } & NORM & 137.04 & 25.77 & \multirow[t]{2}{*}{$>0.01$} & 85.27 & 14.22 & \multirow[t]{2}{*}{$>0.01$} \\
\hline & HIGH & 131.89 & 22.7 & & 82.8 & 12.01 & \\
\hline \multirow[t]{2}{*}{ Bilirubin } & NORMAL & 138.9 & 22.2 & \multirow[t]{2}{*}{$<0.01$} & 86.1 & 12.6 & \multirow[t]{2}{*}{$<0.01$} \\
\hline & HIGH & 123.8 & 23.0 & & 78.7 & 11.8 & \\
\hline
\end{tabular}

From table 3 we can conclude that there was no statistically significant difference between different variable categories and Systolic BP as well as Diastolic BP except for the variable Bilirubin. High Bilirubin level are found in those with low $\mathrm{BP}$ or vice versa. 
Table- 4: Comparing the means of systolic and Diastolic BP with BMI, and CRP categories.

\begin{tabular}{|c|c|c|c|c|c|c|c|c|}
\hline & \multicolumn{4}{|c|}{ With Systolic BP } & \multicolumn{4}{|c|}{ With Diastolic BP } \\
\hline & & $\begin{array}{c}\text { Mean } \\
\text { square }\end{array}$ & $\mathbf{F}$ & SIGN & & $\begin{array}{c}\text { Mean } \\
\text { square }\end{array}$ & $\mathbf{F}$ & SIGN \\
\hline \multirow[t]{2}{*}{ BMI } & $\begin{array}{l}\text { Between } \\
\text { group }\end{array}$ & 1068.3 & \multirow[t]{2}{*}{1.92} & \multirow[t]{2}{*}{$>0.01$} & $\begin{array}{c}\text { Between } \\
\text { group }\end{array}$ & 658 & \multirow[t]{2}{*}{4.28} & \multirow[t]{2}{*}{$<0.01$} \\
\hline & $\begin{array}{l}\text { Within } \\
\text { group }\end{array}$ & 556 & & & $\begin{array}{l}\text { Within } \\
\text { group }\end{array}$ & 153 & & \\
\hline \multirow[t]{2}{*}{ CRP } & $\begin{array}{l}\text { Between } \\
\text { group }\end{array}$ & 6643 & \multirow[t]{2}{*}{13.5} & \multirow[t]{2}{*}{$<0.01$} & $\begin{array}{c}\text { Between } \\
\text { group }\end{array}$ & 2288 & \multirow[t]{2}{*}{16.7} & \multirow[t]{2}{*}{$<0.01$} \\
\hline & $\begin{array}{l}\text { Within } \\
\text { group }\end{array}$ & 489 & & & $\begin{array}{l}\text { Within } \\
\text { group }\end{array}$ & 136 & & \\
\hline
\end{tabular}

From table 4 we can conclude that there was a statistically significant difference in systolic BP between the 3 CRP groups but not with four BMI groups. There was a statistically significant difference in diastolic BP between the 3 CRP groups as well as the four BMI groups.

Table-5: Prediction of different variables based on other independent variables collected in the study.

\begin{tabular}{|c|c|c|c|c|c|}
\hline $\begin{array}{c}\text { Variable } \\
\text { Prediction }\end{array}$ & $\begin{array}{c}\text { Independent } \\
\text { Variables }\end{array}$ & $\begin{array}{c}\text { Regression } \\
\text { Coefficient }\end{array}$ & df & F & SIGN \\
\hline Systolic BP & $\begin{array}{c}104+4(\text { CRP)+(-13.7) } \\
\text { (total bilirubin)+ } \\
1.79(\text { SAD) }\end{array}$ & 0.44 & 4 & 9.552 & $<0.01$ \\
\hline Diastolic BP & $\begin{array}{c}62.08+3.46(\mathrm{CRP}) \\
+0.17 \text { (waist circum) }\end{array}$ & 0.46 & 5 & 8.557 & $<0.01$ \\
\hline
\end{tabular}

Table 5 shows that systolic and diastolic BP could be predicted with the various independent variables used in the study.

\section{Discussion}

Anthropometric and certain other parameters were correlated with systolic and diastolic blood pressures of the study subjects. In our study, it was found that CRP was significantly associated with both systolic and diastolic blood pressure which was also found to be statistically significant with $\mathrm{p}$ value $<0.05$. This finding is consistent with study done by Sung $\mathrm{KC}$ et al [22]. The odds ratio was also found to be very high which signifies a strong association between blood pressure and CRP levels. The diabetic patients were excluded in our study since it might confound the result, as diabetics are prone to infections which may inturn rise CRP levels [22]. In yet another study done by, Schillaci G, it is shown that elevated CRP was associated with increased Systolic Blood pressure only and not with Diastolic blood pressure [23]. Statins and other antihypertensive medications especially angiotensin II receptor blockers are thought to reduce CRP levels [24, 25 , and 26]. But because of feasibility reasons we have not excluded these in our study.
Our study revealed a negative correlation between serum Bilirubin and both systolic and diastolic blood pressures. A study done by Katurzyna Bergmann et al, showed similar findings except that they had found correlation with other parameters also, like waist hip ratio, apo B, apo A, non HDL-C [27]. Since the objective of this study was only to compare some selected parameters with blood pressure, such correlations were not attempted in our study.

When anthropometric parameters are considered in our study, we have measured weight, waist circumference, BMI, waist hip ratio, waist height ratio, hip circumference and sagittal abdominal diameter. It was found that waist circumference, waist height ratio and sagittal abdominal diameters had a statistically significant correlation with systolic and diastolic blood pressure but with a small correlation coefficient. Similar positive correlation of SAD and waist circumference was found in studies done by Souza C [28] and Oliveira 
J [29]. In the present study, a regression analysis was done which found SAD to be an independent risk factor which predicted SBP and waist circumference which predicted DBP. Riserus et al found that SAD showed the strongest correlation to the majority of the individual risk factors among men, whereas in women SAD was equal to that of Waist circumference [21].

\section{Conclusions and Recommendation}

Our study setting was a rural tertiary care hospital situated in Karnataka. We still could demonstrate that elevated CRP, low Bilirubin levels, abnormal SAD and Waist circumference were associated with higher blood pressure levels. Our data suggests these parameters are useful and cost-effective tool for predicting and evaluating Hypertension.Further research with bigger sample and a better sampling technique needs to be done more so in an urban setting so that the findings could be generalized. Future researchers can take that interesting topic and do research on it.

Funding: Nil, Conflict of interest: None initiated.

Permission from IRB: Yes

\section{References}

1. Harrison DG, Guzik TJ, Lob HE, Madhur MS, Marvar PJ, Thabet SR et al. Inflammation, immunity, and hypertension. Hypertension 2011; 57(2): 132-40.

2. Androulakis ES, Tousoulis D, Papageorgiou N, Tsioufis C, Kallikazaros I, Stefanadis C. Essential hypertension: is there a role for inflammatory mechanisms? Cardiol Rev 2009 Sep-Oct;17(5): 216-21.

3. Rajesh K, Suchet, Kochhar S. C-reactive protein and severity of hypertension. JARBS 2013; 5 (4) :331-35.

4. Hage FG. C-reactive protein and hypertension. J Hum Hypertens. 2014 Jul;28(7):410-5. doi: 10.1038/ jhh. 2013.111. Epub 2013 Nov 14.

5. Tatami Y, Suzuki S, Ishii H, Shibata Y, Osugi N, Ota $\mathrm{T}$ et al. Impact of serum bilirubin levels on carotid atherosclerosis in patients with coronary artery disease. IJC Metab Endocr 2014;5: 24-27.

6. Sacerdoti D, Escalante B, Abraham NG, McGiff JC, Levere RD, Schwartzman ML. Treatment with tin prevents the development of hypertension in spontaneously hypertensive rats. Science. 1989 Jan; 243(4889): 388-90.
7. Stec DE, Drummond HA, Gousette MU, Storm MV, Abraham NG, Csongradi E. Expression of heme oxygenase-1 in thick ascending loop of henle attenuates angiotensin II-dependent hypertension. J Am Soc Nephrol. 2012 May; 23(5): 834-41. doi: 10.1681/ ASN. 2011050455. Epub 2012 Feb 9.

8. World Health Organization. World Health Report. Obesity, high blood pressure, high cholesterol, alcohol and tobacco. The World Health Organization's Response. Available at http://www. who. int/whr/ media_centre/ factsheet3/en/

9. Oliveira JS, Amorim PRS, Rosado GP, Ribeiro RCL, Franceschini SCC, Santos TM, Rosado LE. Waist Circumference and Sagittal Abdominal Diameter as Markers of Blood Pressure Abnormality. J Hum Nutr Food Sci 2014;2(2): 1031.

10. Vander Kooy K, Leenen R, Seidell JC, et al. : Abdominal diameters as indicators of visceral fat:Comparison between magnetic resonance imaging and anthropometry. Br J Nutr 1993 Jul; 70 (1) : 47-58.

11. Sampaio LR, Simões EJ, Assis AMO, Ramos LR. Validity and reliability of the SAD as a predictor of visceral abdominal fat. Arq Brase Endocrinol Metabol 2007 Aug; 51(6): 980-86.

12. World Health Organization. Hypertension control. Report of WHO expert Committee. Geneva, Switzerland: World Health Organ Tech Rep Ser. 1996;862:1-83.

13. Bose K, Ghosh A, Roy S, Gangopadhyay S. Blood pressure and waist circumference: an empirical study of the effects of waist circumference on blood pressure among Bengalee male jute workers of Belur, West Bengal, India. J Physiol Anthropol Appl Human Sci 2003 Jul; 22(4) : 169-73.

14. Shanthirani CS, Pradeepa R, Deepa R, Premalatha G,Saroja R, Mohan V. Prevalence and risk factors of hypertension in selected South Indian population - the Chennai Urban Population Study. J Assoc Physicians India 2003 Jan; $51: 20-7$.

15. Gupta R, Mehrishi S. Waist-hip ratio and blood pressure correlation in an urban Indian population. $\mathbf{J}$ Indian Med Assoc 1997 Jul; 95(7) : 412-5. 
16. Shanthirani CS, Pradeepa R, Deepa R, Premalatha G, Saroja R, Mohan V. Prevalence and risk factors of hypertension in selected South Indian population - the Chennai Urban Population Study. J Assoc Physicians India 2003 Jan; $51: 20-7$.

17. Chobanian AV, Bakris GL, Black HR, Cushman WC, Green LA, Izzo Jr JL et al. Seventh Report of the Joint National Committee on Prevention, Detection, Evaluation, and Treatment of High Blood Pressure. Hypertension. 2003 Dec; 42 (6): 1206 - 52. Epub 2003 Dec 1.

18. World Health Organization. The Asia-Pacific Perspective: Redefining Obesity and its treatment. Geneva, Switzerland: WHO; 2000. Available from http:// www. wpro. who. int /nutrition/documents /docs/ Redefiningobesity. pdf

19. Alberti KG, Zimmet P, Shaw J. The metabolic syndrome-a new worldwide definition. The Lancet 2005; 366 (9491); 1059-62.

20. Noble RE. Waist to hip ratio versus BMI as predictors of cardiac risk in obese adult women. West $\mathbf{J}$ Med. 2001 Apr; 174(4): 240-41.

21. Ris'erus U, Faire U, Berglund L, Hell'enius ML. Sagittal Abdominal Diameter as a Screening Tool in Clinical Research: Cutoffs for Cardiometabolic Risk. J Obes. 2010;2010. pii: 757939. doi: 10.1155/ 2010/ 757939. Epub 2010 Mar 11.

22. Sung KC, Suh JY, Kim BS, Kang JH, Kim H, Lee $\mathrm{MH}$ et al. High sensitivity $\mathrm{C}$-reactive protein as an independent risk factor for essential hypertension. Am J Hypertens.2003;16(6): 429-33.
23. Schillaci G, Pirro M, Gemelli F, Pasqualini L, Vaudo G, Marchesi S et al. Increased C-reactive protein concentrations in never-treated hypertension: the role of systolic and pulse pressures. J Hypertens. 2003; 21:1841-46.

24. Ridker PM, Danielson E, Fonseca FA, Genest J, Gotto Jr AM, Kastelein JJ et al.Reduction in C-reactive protein and LDL cholesterol and cardiovascular event rates after initiation of rosuvastatin: a prospective study of the JUPITER trial.Lancet 2009; 373(9670): 1175-82.

25. Fliser D, Buchholz K, Haller H. Antiinflammatory effects of angiotensin II subtype 1 receptor blockade in hypertensive patients with micro inflammation. Circulation 2004; 110(9): 1103-07.

26. Ridker PM, Danielson E, Rifai N, Glynn RJ. Valsartan, Blood pressure reduction, and C-reactive protein: Primary report of the Val-MARC trial. Hypertension 2006; 48(1):73-79.

27. Bergmann K, Pachota E, Sypniewska GO. Association of serum total bilirubin with traditional and novel cardiovascular risk factors in apparently healthy subjects. Folia Med. Copernicana 2015; 3 (1): 26-31.

28. de Souza NC, de Oliveira EP. Sagittal abdominal diameter shows better correlation with cardiovascular risk factors than waist circumference and BMI. J Diabetes Metab Disord. 2013 Jul 15;12:41. doi: 10.1186/2251-6581-12-41. eCollection 2013.

29. Oliveira JS, Amorim PRS, Rosado GP, Ribeiro RCL, Franceschini SCC, Santos TM , Rosado LE. Waist Circumference and Sagittal Abdominal Diameter as Markers of Blood Pressure Abnormality. J Hum Nutr Food Sci 2014;2(2): 1031.

\section{How to cite this article?}

Rao K. S. P, Prasad J. R, Atif M, Bhat R, Rao G, Shivaraja Shankara Y. M. Study of relationship between CRP, bilirubin and selected anthropometric parameters with hypertension. Int J Med Res Rev 2016;4(6):896-902doi: 10.17511/ijmrr.2016.i06.06. 